\title{
Öğrenci ve Öğretmenlerin Covid-19 Salgını Dönemindeki Uzaktan Eğitim Algısı: Bir Metafor Analizi
}

DOI: 10.26466/opus.913396

\author{
* \\ Murat Cokyaman * - Menderes Ünal ** \\ * Dr. Öğr., Ahi Evran Üniversitesi/Eğitim Bilimleri ABD, Kırşehir/Türkiye \\ E-Posta: m.cokyaman@hotmail.com \\ ORCID: $\underline{0000-0002-9682-5036}$ \\ ** Doç. Dr., Ahi Evran Üniversitesi/Eğitim Fakültesi, Kırşehir/Türkiye \\ E-Posta: menderesunal@gmail.com \\ ORCID: $\underline{0000-0001-9439-3308}$
}

\section{Öz}

Bu çalışma Covid-19 salgın döneminde gerçekleştirilen uzaktan eğitim faaliyetlerine yönelik öğrenci ve öğretmen algılarının metafor analizi ile ortaya çıkarılmasını amaçlayan olgubilim deseni ile tasarlanmış nitel bir araştırmadır. Çalı̧̧maya 135 öğretmen, 128 öğrenci olmak üzere toplam 263 kişi katılmıştır. Araştırma verileri geliştirilen ölçme aracı ile Google formlar üzerinden çevrimiçi toplanmıştır. Çalışmada elde edilen verilerin analizinde içerik analizi kullanılmıştır. Katılımcılar tarafından uzaktan eğitimle ilgili oluşturulan metaforlar incelendiğinde, uzaktan eğitim ile ilgili erişim, esneklik, eğitim, etkileşim ve duyuşsal kategorileri ortaya çıkmıştır. Oluşturulan metaforların nitelikleri incelendiğinde hem öğrencilerin hem de öğretmenlerin uzaktan eğitime yönelik genellikle olumlu algzlara sahip oldukları sonucu ortaya çıkmıştır. Öğrencilerin çoğunluğu eğitim, erişim ve esneklik kategorilerinde olumlu algılara sahipken etkileşim ve duyuşsal kategorilerinde olumsuz algilara sahip olduğu öte yandan öğretmenlerin erişim dışında tüm kategorilerde olumlu algılara sahip olduğu sonucuna ulaşılmıştır. Bu bağlamda uzaktan eğitim sistemlerinin tasarlanması, eğitim sistemine entegrasyonu ve uygulanması sürecinde alınacak kararlarda duyuşsal, erişim ve etkileşim kategorilerindeki olumsuz algılarm; eğitim ve esneklik kategorilerindeki olumlu algıların göz önünde bulundurulmast önerilmektedir.

Anahtar Uzaktan Ĕ̆itim, Covid-19, Metafor Analizi.

Kelimeler: 
ISSN:2528-9527

E-ISSN: 2528-9535

YIl Year: 11

Cilt Volume: 18

Sayı Issue: Yönetim ve Organizasyon Özel Sayısı

Temmuz July 2021

Uluslararası Toplum Araştırmaları Dergisi International Journal of Society Researches

Makalenin Geliş Tarihi Received Date: 13/04/2021 Makalenin Kabul Tarihi Accepted Date: 21/05/2021

\title{
Distance Education Perceptions of Students and Teachers during Covid-19 Epidemic: A Metaphor Analysis
}

*

\begin{abstract}
This study is qualitative research with a phenomenological design that aims to reveal perceptions of students and teachers about distance education carried out during the Covid-19 epidemic period. 135 teachers and 128 students participated in the study. Research data were collected online via Google forms with a data collection tool developed by the researchers. Content analysis was used in the analysis of the data. As a result, it was concluded that both students and teachers had positive perceptions about distance education. When the metaphors about distance education created by the participants were examined, the categories of access, flexibility, education, interaction and affective were emerged. When metaphors were examined, it was found that both students and teachers generally had positive perceptions of distance education. While most of the students had positive perceptions in the education, access and flexibility categories, it was concluded that they had negative perceptions in the interaction and affective categories; on the other hand, teachers had positive perceptions in all categories except access. In this context, in the decisions to be taken during the design, integration and implementation of distance education systems, it is suggested to consider the negative perceptions in affective, access and interaction categories $s$ and positive perceptions in education and flexibility categories.
\end{abstract}

Keywords Distance Education, Covid-19, Metaphor Analysis. 


\section{Giriş}

Bireylerin gereksinim ve ihtiyaçları eğitim öğretim faaliyetlerinin nasıl yürütüleceğini belirleyen en önemli faktörlerden bir tanesidir. İçinde bulunduğumuz 21. yüzyılda, bilgi ve iletişim teknolojileri hızla gelişmekte neredeyse her gün yeni kavramlar ve uygulamalar hayatımıza girmektedir. Teknolojideki bu değişim her alanda olduğu gibi eğitim alanında da insanların ihtiyaç ve gereksinimlerini günden güne değiştirmektedir. Noam (1995) "eskiden insanlar bilgiye gelirdi ve bilgi üniversitelerdeydi; gelecekte ise insanlar nerede olurlarsa olsunlar bilgiler onlara gelecektir" (akt. Moore, 2002) şeklindeki ifadesi aslında eğitim ve öğretimde bir paradigma değişikliğinin olabileceğinin bir göstergesidir, dolayısıyla dijital çă̆ olarak da adlandırılan bu dönemde bireyler kendilerine zaman ve mekân bağımsızlığı sağlayacak, kendilerini daha özgür hissettikleri esnek bir öğrenme anlayışına yönelmektedir. Bu bağlamda uzun yıllardır alışlagelen yüz yüze eğitime alternatif olarak uzaktan eğitim kavramı karşımıza çıkmaktadır.

Uzaktan eğitim geleneksel yüz yüze öğretme-öğrenme etkinliklerinin sinırlılıklardan dolayı sınıf içi etkinliklerin yürütülme olanağının bulunmadığ 1 durumlarda, bu etkinlikleri planlayan, uygulayan ve öğrenciler arasındaki iletişim ve etkileşimin farklı eğitim ortamlarıla sağlandığı bir öğretim yöntemidir (Alkan, 1987). Moore ve Kearsley (1995) ise uzaktan eğitimi öğrenci ve öğretmenlerin farklı mekânlarda bulunduğu, özel ders tasarımları ile öğretim yöntemlerinin uygulanmasını ve çeşitli teknolojilerinin kullanılmasını gerektiren, planlı, kurumsal ve yönetsel bir düzenleme olarak tanımlamaktadır. Her iki tanım incelendiğinde uzaktan eğitim öğrenci ve öğretmenin yüz yüze olmadığı durumlarda çeşitli teknolojik araçlar vasıtasıyla öğrenme ve öğretme etkinliklerinin gerçekleştirilmesi olarak tanımlanabilir.

Avrupa Uzaktan Öğretim Üniversiteler Birliğinin (EADTU) Exellence projesine göre, uzaktan eğitimin temel özellikleri erişilebilirlik, esneklik, etkileşim ve bireyselleştirme olarak belirlenmiş ve bu özelliklerin geliştirilmesi hedeflenmiştir (EADTU, 2013; akt. Demir, 2014). Bu özellikler düşünüldüğünde uzaktan eğitimin hem avantajları hem de dezavantajları bulunmaktadır. Uzaktan eğitimin avantajları düşük maliyetli olması, uygulamada standart sağlayabilmesi, daha kolay kitle 
eğitimi yapılabilmesi, ihtiyaç duyulan yer ve zamanda yapılabilmesi, çok yönlü olması, yüz yüze eğitim alamayan dezavantajlı grupların eğitime dâhil edilebilmesi, bireye öğrenmeyle ilgili sorumluluk kazandırması vb. olarak sıralanabilir (Akyürek, 2020; Arat ve Bakan, 2014; Elcil ve Şahiner, 2014; Gökbulut, 2021).

Uzaktan eğitimin uygulamalı dersler için etkili olmaması, karşılıklı etkileşim sınırlılığı, öğrenenlerin sosyalleşmesini engellemesi, iletişim teknolojilerine bağımlılık, uygun donanıma herkesin sahip olamaması, teknik aksaklıklar, bireysel veya bağımsız öğrenme alışkanlığı olmayan öğrencilerin motivasyonlarının düşük olması, ölçme ve değerlendirmede yaşanan zorluklar, teknolojiye yabancı bireylerin problem yaşaması, anında tam olarak dönüt verilememesi gibi özellikleri dezavantajları olarak söylenebilir. (Demir, 2014; Karataş 2008; Kılınç, 2015; Umurhan, 2014; Uşun, 2006). Bu avantaj ve dezavantajlarının eş zamanlı ve eş zamanlı olmayan uzaktan eğitim türlerine göre değişebileceği de göz önünde bulundurulmalıdır. Bu bağlamda öğrenci ve öğretmenin aynı anda çevrimiçi derse katıldıkları eş zamanlı uzaktan eğitimin, öğrencilerin kendine en uygun zamanda çevrimiçi derse katıldığı eş zamanlı olmayan uzaktan eğitime göre daha fazla avantajının olduğu söylenebilir.

Uzaktan eğitimin belli başlı dezavantajlarına rağmen, dijitalleşmenin etkisiyle beraber kullanım alanının genişlediği görülmektedir. Güçlü (2016) uzaktan eğitimin çağdaş bir eğitim yaklaşımı olduğunu vurgulamakta; hızlı ve etkin bir eğitim yöntemi olarak görüldüğü için yoğun bir şekilde kullanıldığını belirtmektedir. Yükseköğretim Kurulu verilerine göre Türkiye'de yükseköğretimde uzaktan eğitime kayıtlı öğrenci sayısı 2014-2015 eğitim-öğretim yılında 59882 iken bu sayı 20182019 eğitim-öğretim yılında 82457 olmuştur 5 yıllık sürede neredeyse yarıya yakın bir artış olduğu söylenebilir.

2019 yılında Çin'de başlayarak tüm dünyaya yayılan Covid-19 salgını nedeniyle uzaktan eğitim kavramı sıklıkla telaffuz edilmeye başlanmıştır. Küresel çaptaki bu salgın nedeniyle birçok ülkede okullar tatil edilmiş ve bazı ülkelerde uzaktan eğitim yoluyla dersler telafi edilmeye çalışılmıştır. Türkiye de uzaktan eğitimin en çok kullanıldığı ülkelerden biridir. Öncelikle mesajlaşma uygulamalarındaki öğrenci-öğretmen gruplarıyla başlayan uzaktan eğitim veya etkileşim, telekonferans sistemine dayanan karşılıklı görüşme programlarıyla devam etmiştir. Uzaktan eğitim, 
yükseköğretimde üniversitelerin uzaktan eğitim programları ile bir düzene oturtulurken, ilk ve ortaöğretimde hali hazırda kullanılan Eğitim Bilişim Ağ 1 (EBA) ile öğrencilere uzaktan eğitim desteği sağlanmıştır. Bu bağlamda öncelikle EBA içeriğindeki mevcut imkânlara Milli Eğitim Bakanlığının (MEB) müfredatını takip eden ders anlatım videolarının yayınlandığı EBA TV eklenmiştir. Daha sonra EBA canlı ders uygulaması ile öğrencilerin kendi öğretmenleriyle canlı olarak uzaktan eğitim almaları sağlanmiştır.

Covid-19 salgınının ilk dönemindeki uzaktan eğitim faaliyetlerinde her öğrenci ve öğretmen, kendi imkân ve kişisel durumuna göre farklı uzaktan eğitim araçlarından faydalanmıştır. Dolayısıyla herkesin zihninde farklı bir uzaktan eğitim algısı oluşmaktadır. Örneğin, bazı öğretmen veya öğrenciler gönüllü olarak uzaktan eğitim faaliyetlerine katılıyor olabilirken bazıları çeşitli zorunluluklardan dolayı katılıyor olabilir ya da kimileri bu durumu faydalı buluyorken kimileri de yararsız olduğunu düşünebilir. Bu bağlamda bireylerin zihinlerindeki uzaktan eğitim algısının ortaya konulması önem taşımaktadır. Yılmaz ve Güven (2015) uzaktan eğitimle ilgili yaşanan deneyimler ve bu konuda bilgi sahibi olmanın uzaktan eğitime yönelik algılarını ve bu algıların da uzaktan eğitimden elde edilen başarıyı etkilediğini ifade etmektedir. Konu ile ilgili yapılan çeşitli çalışmalarda uzaktan eğitime yönelik olumlu algılara sahip olmanın eğitimden elde edilen başarı düzeyi ve öğrenci performansları arasında olumlu bir ilişki olduğu ortaya konulmuştur (İbicioğlu ve Antalyalı, 2005; İrani, Telg, Scherler ve Harrington, 2003; Kırali ve Alc1, 2016). Benzer şekilde Schutz ve Pekrun (2007) olumsuz algıların öğrencilerin öğrenme ve başarı düzeyini olumsuz etkilediğini ifade etmektedir. Dolayısıyla öğrenci ve öğretmenlerin uzaktan eğitimi algılama biçimleri yüz yüze eğitimin yapılamadığı bu dönemde gerçekleştirilen uzaktan eğitim faaliyetlerinin etkililiği ve geleceği ile ilgili ipuçları ortaya koyabilir.

$\mathrm{Bu}$ çalışma ile öğrenci ve öğretmenlerin uzaktan eğitime yönelik algıların metaforlar aracılığıyla ortaya çıkarılması amaçlamıştır. Araştırma özelinde uzaktan eğitim kavramı ile Covid-19 salgınının ilk döneminde yüz yüze yapılamayan eğitim faaliyetlerini telafi etmek için uzaktan eğitim programları, telekonferans sistemine dayanan programlar ve mesajlaşma uygulamalarındaki öğrenci-öğretmen grupları üzerinden 
yapılan eğitim-öğretim faaliyetleri kastedilmektedir. Araştırmanın amacı doğrultusunda şu sorulara yanıt aranmıştır:

1. Öğrencilerin uzaktan eğitime ilişkin metaforik algıları nedir?

2. Öğretmenlerin uzaktan eğitime ilişkin metaforik algıları nedir?

3. Öğrenci ve öğretmenlerin uzaktan eğitime yönelik metaforik algılarındaki benzer ve farklı noktalar nelerdir?

Literatürde uzaktan eğitim algılarının metaforlar aracılığıyla tespit edilmesine yönelik çeşitli çalışmalar bulunmaktadır (Aydoğdu 2008; Aykaç ve Çelik, 2014; Çivril, Aruğaslan, Özkara, 2018; Erten, 2020; Fidan, 2017; Tuncay ve Özçınar, 2009, Yılmaz ve Güven 2015). İlgili çalışmalar incelendiğinde örneklemin genellikle öğrenciler, öğretmen veya öğretmen adaylarından birinin oluştuğu görülmektedir. Aykaç ve Çelik (2014) diğerlerinden farklı olarak hem öğretmen hem de öğretmen adayları üzerinde çalışmıştır. Bu çalışmada ise konuyla ilgili yapılan diğer çalışmalardan farklı olarak değişik kademelerdeki hem öğrenci hem de öğretmenlerin algılarının tespit edilmesi amaçlanmıştır. Ayrıca araştırmanın Covid-19 salgını dönemindeki uzaktan eğitim ile ilgili yapılan ilk metafor çalışmaları arasında olacağı düşünülmektedir.

\section{Yöntem}

$\mathrm{Bu}$ çalışma öğrenci ve öğretmenlerin uzaktan eğitimle ilgili algılarının metaforlar aracılığıyla ortaya konulmasını amaçlayan olgubilim deseni ile tasarlanmış nitel bir araştırmadır. Olgubilim çalışmaları ile günlük deneyimlerimizin doğası veya anlamı hakkında daha derin bir anlayış kazanmak amaçlanmaktadır (Patton, 2002). Bu bağlamda araştırılacak olgular günlük yaşamda sıklıkla tecrübe edilen ancak derinlemesine ve ayrıntılı görüş sahibi olunamayan duygular, ilişkiler, kültürler, olaylar vb. olabilir. Böylelikle tümüyle bize yabancı olmayan aynı zamanda tam anlamıyla kavrayamadığımız olguları ayrıntılı bir şekilde araştırmayı amaçlayan çalışmalar için olgu bilim uygun bir araştırma zemini oluşturur. Öte yandan elde edilen sonuçların nitel araştırmanın doğası gereği kesin ve genellenebilir olmayacağı unutulmamalıdır çünkü bu çalışma deseniyle bir olgunun daha iyi tanınması ve anlaşılmasına yardımcı olacak örnekler, açıklamalar ve yaşantılar ortaya konulabilir (Yıldırım ve Şimşek, 2016). Bu bağlamda araştırmadan elde edilen 
sonuçların genellenmesi değil uzaktan eğitimle ilgili zengin ve ayrıntılı görüşlerin metaforlarla ortaya çıkarılması amaçlanmıştır.

\section{Evren ve örneklem}

Çalışma evreni İç Anadolu Bölgesinde yer alan bir şehirdeki öğrenci ve öğretmenlerden oluşmaktadır. Çalışmada içinde bulunulan salgın dönemi nedeniyle uygun örnekleme yöntemi kullanılmıştır. Uygun örnekleme, ulaşılabilirlik ve elverişlilik esasına dayalı olup araştırma verilerinin hızlıca toplanmasını sağlayan bir örneklem yöntemidir (Berg, 2001). Katılımcılardan uzaktan eğitimle ilgili bir metafor oluşturmaları istenmiştir. Toplanan veriler sonucu 314 katılımcı formu doldurmuştur. Elde edilen veriler incelenerek metafor özelliği göstermeyen veriler araştırmadan çıartılmış ve toplam katılımcı sayısı 135 öğretmen, 128 öğrenci olmak üzere 263 olarak tespit edilmiştir. Öğretmen ve öğrencilere ait demografik özellikler Tablo 1 ve Tablo 2'de sunulmuştur.

Tablo 1. Öğretmenlere ait demografik özellikler

\begin{tabular}{llll}
\hline Demografik Özellikler & Tür & f & \% \\
\hline \multirow{3}{*}{ Cinsiyet } & Kadın & 64 & 52,6 \\
& Erkek & 71 & 47,4 \\
\hline \multirow{3}{*}{ Okul Kademesi } & Illkokul & 24 & 16,4 \\
& Ortaokul & 72 & 51,9 \\
& Lise & 28 & 20,7 \\
& Anaokulu & 11 & 8,1 \\
& Diğer & 3 & 2,9 \\
\hline \multirow{3}{*}{ Okul Türü } & Devlet & 132 & 97,8 \\
\hline \multirow{3}{*}{ Kıdem } & Özel & 3 & 2,2 \\
& $0-5$ yıl & 26 & 19,3 \\
& 6-10 yıl & 31 & 23,0 \\
& $11-15$ yıl & 35 & 25,8 \\
& 16-20 yıl & 19 & 14,1 \\
Branş & 20 yıl üzeri & 24 & 17,8 \\
& Güzel Sanatlar ve Spor (Beden-Resim-Müzik) & 12 & 8,8 \\
& Bilişim Tek. & 4 & 3,0 \\
& Fen Bilimleri & 13 & 9,6 \\
& Yabancı dil (İngilizce-Almanca-Arapça) & 26 & 19,2 \\
& Matematik & 15 & 11,1 \\
& Okul Öncesi & 11 & 8,1 \\
& Sinıf Öğretmeni & 20 & 14,8 \\
& Sosyal Bilgiler (Tarih-Coğrafya) & 13 & 9,6 \\
& Türkçe ve Edebiyat & 13 & 7,7 \\
& Diğer & 8 & 5,8 \\
\hline
\end{tabular}


Cinsiyet ve kıdem boyutlarında dengeli bir dağılım olduğu görülmektedir. Katılımcıların büyük bir çoğunluğu ortaokul öğretmeni ve devlet okullarında çalışmaktadır. Branş bazında en yüksek katılımın İngilizce branşında olduğu görülmektedir.

Tablo 2. Öğrencilere ait demografik özellikler

\begin{tabular}{llll}
\hline Demografik Özellikler & Tür & f & \% \\
\hline \multirow{2}{*}{ Cinsiyet } & Kiz & 73 & 57 \\
& Erkek & 55 & 43 \\
\hline \multirow{2}{*}{ Okul Kademesi } & Ortaokul & 67 & 52,3 \\
& Lise & 24 & 18,8 \\
& Üniversite & 37 & 28,9 \\
\hline \multirow{2}{*}{ Okul Türü } & Devlet & 125 & 97,8 \\
& Özel & 3 & 2,2 \\
\hline
\end{tabular}

Tablo incelendiğinde katılımcların cinsiyet dağılımının birbirine yakın olduğu, katılımcıların yarısından fazlasının ortaokul öğrencisi olduğu ve neredeyse tamamına yakının devlet okullarında öğrenim gördükleri söylenebilir.

\section{Veri Toplama Aracı}

Bu çalışmada katılımcıların "uzaktan eğitim" ile ilgili algılarını ortaya çıkarmak amaciyla Google formlar üzerinden bir veri toplama aracı hazırlanmıştır. Hazırlanan form için 3 eğitim bilimleri uzmanından görüş alınmıştır. Veri toplama aracının ilk bölümü demografik özelliklerinin tespitine yöneliktir. $\mathrm{Bu}$ bölümde katılım durumunun öğrenci veya öğretmen olmasına göre demografik özellik değişkenleri farklıdır. İkinci bölümde ise katılımcıların uzaktan eğitim deneyimlerini belirlemek amaçlanmıştır. Son bölümde ise uzaktan eğitime ait metaforların belirlenmesi için katılımcılardan "Uzaktan Eğitim ......... gibidir, çünkü ." cümlesini tamamlamaları istenmiştir. Hazırlanan veri toplama aracının bağlantı adresi katılımcılarla elektronik ortamda paylaşılarak veriler toplanmıştır. 


\section{Verilerin Analizi}

Çalışmada elde edilen metaforların içerik analizi yapılmıştır. Uzaktan eğitimle ilgili zengin ve ayrıntılı görüşleri ortaya çıkarmak için metaforlardan yararlanılmıştır. Aykaç ve Çelik (2014) metaforları kavramların anlaşılması için zihinsel süreçleri düzenlemek adına günlük hayatımızda bilinçli veya bilinçsiz olarak kullandığımız, benzetmeler aracılığıyla anlamlandırma ve somutlaştırma araçları olarak tanımlamaktadır. Yıldırım ve Şimşek (2006) mecaz odaklı bir çalışmada bir veya birkaç soruyla araştırılan olgu, olay ve konu ile ilgili çok zengin veriler elde edilebileceğini belirtmektedir. Üretilen her bir mecaz kişinin kendi bakış açısı, yaşantı ve deneyimi etrafında şekillenmektedir. Dolayısıyla mecazlar bir kavram ile ilgili belki de yüzlerce kelimenin anlatamayacağı bir manzara ortaya koyar ki Sackmann (1989) bu durumu yani mecazların görsel gücünün -karmaşık bir hikâyeyi görseller kullanarak aktarması- onları çok etkili ve güçlü iletişim araçları haline getirdiğini belirtmektedir (Yıldırım ve Şimşek, 2016).

\section{Bulgular}

Araştırma bulguları, metaforları olumlu-olumsuz ve kategori-tema olmak üzere, iki boyutta tablolaştırılmıştır ve araştırma problemlerine göre başlıklar altında sunulmuştur. Ayrıca metaforlarla ilgili bulgulardan önce araştırma grubunun uzaktan eğitim deneyimleri ve kullanım durumlarına ilişkin bilgiler sunulmuştur.

\section{Öğrencilerin uzaktan eğitim algılarına ilişkin bulgular}

Öğrencilerin uzaktan eğitime ilişkin metaforların ortaya çıkarılması ve bunların anlaşılır bir şekilde analiz edilebilmesi için öncelikle öğrencilerin uzaktan eğitim deneyimlerinin olup olmadığı, uzaktan eğitimi kullanım sıklıkları ve kullandıkları uzaktan eğitim platformlarının incelenmesi gerekmektedir. Tablo 3 'te öğrencilerin uzaktan eğitim kullanım durumlarına ilişkin bilgiler yer almaktadır. 
Tablo 3. Öğrencilerin uzaktan eğitim kullanım durumları

\begin{tabular}{llll}
\hline Boyut & Durum & f & $\mathbf{\%}$ \\
\hline Uzaktan Eğitim & Evet & 122 & 95,3 \\
Deneyimi & Hayır & 6 & 4,7 \\
\hline \multirow{3}{*}{ Uzaktan Eğitim } & Haftalık 1-5 ders arasında & 52 & 40,6 \\
Kullanım Sıklı̆̆ı & Haftalık 6-10 ders arasında & 50 & 39,1 \\
& Haftalık 11-15 ders arasında & 15 & 11,7 \\
& Haftalık 15 ders üzeri & 5 & 3,9 \\
& Hiç & 6 & 4,7 \\
\hline \multirow{3}{*}{ Tür } & EBA Canlı Ders & 79 & - \\
& Mesajlaşma uygulamalarındaki sınıf grupları & 61 & - \\
& Telekonferans programları & 57 & - \\
& Üniversitelerin uzaktan eğitim programları & 23 & - \\
\hline
\end{tabular}

Tablo 3 incelendiğinde araştırmaya katılan öğrencilerin sadece $\% 4,7^{\prime} \operatorname{sinin}$ aktif bir şekilde uzaktan eğitim deneyimi olmadığ1 anlaşılmaktadır. Uzaktan eğitim kullanımlarında ise haftalık 1-5 ders arası ve 6-10 ders arası sıklığının en çok orana sahip oldukları görülmektedir. Uzaktan eğitimde platformları incelendiğinde ise en çok EBA canlı dersin tercih edildiği görülmektedir. Kullanılan platformlar sorusunda birden fazla tür işaretlenebildiği için yüzdelik oranlar hesaplanmamıştır. Bu veriler 1şığında araştırmaya katılan öğrencilerin ideal düzeyde uzaktan eğitim deneyimi olduğu ve bu sistemi kullandıkları söylenebilir.

Öğrencilerin oluşturdukları metaforlar analiz edildiğinde "Duyuşsal", "Eğitim", "Erişim", “Esneklik", ve "Etkileşim" olmak üzere 5 kategori ortaya çıkmıştır. Kategori ve temaların oluşturulmasında Çivril vd. (2018)' nin çalışmasından faydalanılmıştır. “Duyuşsal” kategorisi uzaktan eğitim ile ilgili duygusal yönden düşünceleri ve uzaktan eğitimin ne gibi duygular oluşturduğunu ortaya çıarmaktadır. "Eğitim" kategorisi uzaktan eğitimin eğitim-öğretim faaliyetlerindeki avantaj ve dezavantajları ifade etmektedir. "Erişim" kategorisi öğrenci ve öğretmenlerin uzaktan eğitime erişimleri noktasındaki deneyim ve tecrübeleri ile ilgilidir. "Esneklik" kategorisi uzaktan eğitimin bireysel farklılara göre sağlamış olduğu öğrenme ortamı, yeri ve zamanını ifade etmekteyken "Etkileşim" kategorisi ise uzaktan eğitimin öğrenen ve öğreten arasındaki bağlantı ve ilişkileri kapsamaktadır.

Öğrenci metaforlarının kategorileri ile bu kategorilerdeki olumlu ve olumsuz metafor sayıları Tablo 4'de sunulmuştur. 
Tablo 4. Öğrenci metaforlarının kategorileri ve nitelikleri

\begin{tabular}{lllllll}
\hline & Duyuşsal & Eğitim & Erişim & Esneklik & Etkileşim & Toplam \\
\cline { 2 - 7 } & f & $\mathbf{f}$ & $\mathbf{f}$ & $\mathbf{f}$ & $\mathbf{f}$ & $\mathbf{f}$ \\
\hline Olumlu Metafor & 5 & 46 & 17 & 16 & 4 & 88 \\
Olumsuz Metafor & 7 & 18 & 6 & 0 & 9 & 40 \\
\hline Toplam & 12 & 64 & 23 & 16 & 13 & 128 \\
\hline
\end{tabular}

Öğrencilerin oluşturdukları metaforlar kategori boyutlarına göre incelendiğinde, metaforların yarısının ( $\mathrm{f}=64)$ "Eğitim" ile ilgili olduğu görülürken ardından sırasıyla "Erişim", "Esneklik", "Etkileşim" ve "Duyuşsal" kategorileri gelmektedir. "Eğitim", "Erişim" ve "Esneklik" kategorilerinde öğrencilerin çoğunlukla olumlu görüş belirttiği anlaşılmaktadır. Dolayısıyla uzaktan eğitimin, öğrencilere göre eğitim öğretim faaliyetlerinde olumlu bir etkiye sahip olduğu ve uzaktan eğitime erişim noktasında sıkıntı yaşamadıkları söylenebilir. Ancak araştırma örnekleminin neredeyse tamamına yakının uzaktan eğitim deneyimi olan ve uzaktan eğitime erişimde teknik altyapıya sahip öğrencilerinden oluşması bu sonuca etki etmiş olabilir. "Esneklik" kategorisinde ise dikkat çekici bir şekilde oluşturulan metaforların tamamının olumlu olması uzaktan eğitimin öğrencilere esnek bir öğrenme ortamı sunduğunun göstergesi olabilir. "Duyuşsal" ve "Etkileşim" kategorilerindeki metaforlar çoğunlukla olumsuzdur. Dolayısıyla uzaktan eğitimle ilgili olumsuz duygu ve düşüncelerin olduğu ve uzaktan eğitimin karşılıklı etkileşim konusunda eksik kaldığ1 söylenebilir. Öğrencilerin uzaktan eğitim metaforlarına ilişkin oluşan kategori ve temalar Tablo 5'te sunulmuştur.

Öğrencilerin oluşturdukları metaforlar analiz edildiğinde 5 kategori, 16 tema ve 105 tekrarsız metafor olduğu tespit edilmiştir. Duyuşsal kategorisinde "Bıkkınlık", "Eksiklik", "Zorlayıc1", "Şaşırtıcı" ve "Motivasyon" temaları bulunmaktadır. Bir tanesi olumsuz olmak üzere en çok metafor (4) "Motivasyon" temasındadır. "Bıkkınlık", “Eksiklik" ve "Zorlayıcı" temaları olumsuz algılar içermektedir. "Şaşırtıcı" temasında hem olumlu hem de olumsuz nitelikli ifadeler bulunmaktadır. Bu kategorideki bazı metaforik ifadeler aşağıda yer almaktadır. Metafor ifadelerinin yanında parantez içinde görüş sahibinin kodlanmış kimliği cinsiyeti ("K" Kız ve “E” Erkek) okul türü ("O" Ortaokul, "L" Lise ve "ن̈" Üniversite) ve metaforun tema bilgisine yer verilmiştir 
Tablo 5. Öğrencilerin uzaktan eğitim metaforlarnna ilişkin kategori ve temalar

\begin{tabular}{|c|c|c|c|}
\hline Kategori & Tema & Benzetilen nesne & Metafor \\
\hline \multirow{5}{*}{ Duyuşsal } & Bıkkınlık & Fastfood & $\begin{array}{l}\text { Uzaktan eğitim fastfood gibidir, çünkü bir } \\
\text { süre sonra bayar. }\end{array}$ \\
\hline & Eksiklik & Yarım elma & $\begin{array}{l}\text { Uzaktan eğitim yarım elma gibidir, çünkü } \\
\text { hep bir tarafı eksik kalır. }\end{array}$ \\
\hline & Motivasyon & $\begin{array}{l}\text { Resmi kıyafet, Eğlence, Müzik, Evde spor } \\
\text { yapmak }\end{array}$ & $\begin{array}{l}\text { Uzaktan eğitim resmi kıyafetle gezmek } \\
\text { gibidir, çünkü yüz yüze eğitime göre daha } \\
\text { ciddi ve sıkıcıdır. }\end{array}$ \\
\hline & Şaşırtıcı & $\begin{array}{l}\text { Sürpriz yumurta, Yolda bulunan para, } \\
\text { Elmalı şeker }\end{array}$ & $\begin{array}{l}\text { Uzaktan eğitim sürpriz yumurta gibidir, } \\
\text { çünkü ne zaman ne çıacağı belli değil. }\end{array}$ \\
\hline & Zorlayıc1 & Baba, Kadın, Samanlıkta iğne aramak & $\begin{array}{l}\text { Uzaktan eğitim babam gibidir, çünkü hiçbir } \\
\text { zaman ensemden düşmez. }\end{array}$ \\
\hline \multirow{7}{*}{ Ĕgitim } & Anlaşılmaz & Yabancı dil, Yararsız, Zor & $\begin{array}{l}\text { Uzaktan eğitim yabancı dil gibidir, çünkü } \\
\text { anlaşılmıor ve özümüzden uzaklaştırıor. }\end{array}$ \\
\hline & Okul & $\begin{array}{l}\text { Ders, Tutkal, İdare eden bir şey, Mucize, } \\
\text { Örgün eğitim, Pusula, Okul (5), Okulda } \\
\text { Eğitim, Yedek okul }\end{array}$ & $\begin{array}{l}\text { Uzaktan eğitim örgün gibidir, çünkü } \\
\text { sorunsuz ders işleyebiliyoruz. }\end{array}$ \\
\hline & Fayda & Düşünce, Çekirdek, Güneş, Ucuz alışveriş & $\begin{array}{l}\text { Uzaktan eğitim güneş gibidir, çünkü hem } \\
\text { 1sitır, hem de işıtır. }\end{array}$ \\
\hline & İhtiyaç & $\begin{array}{l}\text { Evrensel, Para, İlaç, Su (2), İftar açmak, } \\
\text { Besin, Araç, Telefon }\end{array}$ & $\begin{array}{l}\text { Uzaktan eğitim iftar açmak gibidir, çünkü } \\
\text { eğitim açlı̆̆ımızı gideriyor. }\end{array}$ \\
\hline & Öğretici & $\begin{array}{l}\text { Sınıf, Kitap (2), Ansiklopedi, Kütüphane, } \\
\text { Öğretmen, Televizyon, Oyun izlemek, } \\
\text { Elmas, Yemek kaşı̆̆ı, Vitamin ilacı, Altın } \\
\text { tepside sunulan fırsat, Kurtarıcı }\end{array}$ & $\begin{array}{l}\text { Uzaktan eğitim kitap gibidir, çünkü bize bilgi } \\
\text { verir bilmediklerimizi öğretir. }\end{array}$ \\
\hline & Verim & $\begin{array}{l}\text { Ağaç, Yağmur, Anne sütü, Su, Güneş (2), } \\
\text { Çiçek, Etkisiz eleman, Şekersiz çay, } \\
\text { Hocasız sınıf, İsraf, Boş ders, Herhangi bir } \\
\text { insanın ders anlatması, Susuz toprak, } \\
\text { Tuzsuz çorba, Çöl }\end{array}$ & $\begin{array}{l}\text { Uzaktan eğitim susuz toprak gibidir, çünkü } \\
\text { normal eğitimden biraz daha verimsizdir. }\end{array}$ \\
\hline & Yetersizlik & $\begin{array}{l}\text { Hızlı pişen yemek, Tadımlık yiyecek, } \\
\text { Sade tablo, Mum, Ara vermek, Akan } \\
\text { zaman }\end{array}$ & $\begin{array}{l}\text { Uzaktan eğitim tadımlık yiyecek gibidir, } \\
\text { çünkü tadımlık kadar azdır. }\end{array}$ \\
\hline \multirow{3}{*}{ Erişim } & Kolaylık & $\begin{array}{l}\text { Kargo, Akilli tahta, Telefon (4), Kumanda } \\
\text { (4), İnternet (2), Teknolojik alet, Anahtar, } \\
\text { Oyuncak }\end{array}$ & $\begin{array}{l}\text { Uzaktan eğitim internet gibidir çünkü bir } \\
\text { tuşla her şey ayağının altındadır. }\end{array}$ \\
\hline & Teknik sorun & $\begin{array}{l}\text { Arızalı araç, Etkisiz eleman, Faydalı, } \\
\text { Kanser, Elektrik kesintisi }\end{array}$ & $\begin{array}{l}\text { Uzaktan eğitim elektrik kesintisi gibidir, } \\
\text { çünkü aniden bağlantı kopabiliyor. }\end{array}$ \\
\hline & Yakınlık & Akraba, Arkadaş, Aile & $\begin{array}{l}\text { Uzaktan eğitim ailem gibidir, çünkü her an } \\
\text { yanımdadır. }\end{array}$ \\
\hline \multirow{2}{*}{ Esneklik } & Kişiye özel & $\begin{array}{l}\text { Kumanda, Özgürlük, Kitap, Televizyon, } \\
\text { Canlı kütüphane, Paket servis, Özgürlük } \\
\text { heykeli, Meyve bahçesi, Müzik }\end{array}$ & $\begin{array}{l}\text { Uzaktan eğitim meyve bahçesi gibidir, çünkü } \\
\text { istediğinden çeşit çeşit yersin. }\end{array}$ \\
\hline & $\begin{array}{l}\text { Zaman ve mekân } \\
\text { Bağımsızlığı }\end{array}$ & $\begin{array}{l}\text { Elimizin altındaki okul, Telefon, Fırsat, } \\
\text { Kuş, Online alışveriş, Hobi, Yazılıda } \\
\text { öğretmenin sınıftan çıması }\end{array}$ & $\begin{array}{l}\text { Uzaktan eğitim bir kuşa benzer, çünkü } \\
\text { istediğin zaman istediğin yere özgürce } \\
\text { ulaşabilirsin. }\end{array}$ \\
\hline \multirow[b]{2}{*}{ Etkileşim } & $\begin{array}{l}\text { İletişim ve } \\
\text { Sosyalleşme }\end{array}$ & $\begin{array}{l}\text { Canlı yayın, İplik, Görüntülü konuşma, } \\
\text { Park, Yetersiz, Buzdolabı, Körebe }\end{array}$ & $\begin{array}{l}\text { Uzaktan eğitim park gibidir, çünkü } \\
\text { arkadaşlarla buluşma mekânıdır. }\end{array}$ \\
\hline & Tek yönlülük & $\begin{array}{l}\text { Haber sunmak, Masal okuyan kitap, } \\
\text { Sinema, Telefon konuşması, Sessiz sinema, } \\
\text { Youtube videosu }\end{array}$ & $\begin{array}{l}\text { Uzaktan eğitim haber sunmak gibidir, çünkü } \\
\text { geri bildirim alamıorsunuz. }\end{array}$ \\
\hline
\end{tabular}

"Uzaktan eğitim müzik gibidir, çünkü evde olduğumuz için bizi rahatlatır." (ÖĞRN11, K, O, Motivasyon)

"Yolda bulunan para gibidir, çünkü hem şaşırır hem mutlu olursun." (ÖĞRN123, E, O, Şaşırtıc1) 
"Samanlıkta iğne aramak gibidir, çünkü iğneyi bulmak çok zordur." (ÖĞRN86, E, Ü, Zorlayıc1)

Eğitim kategorisinde "Okul", "Fayda Durumu", "İhtiyaç" ve "Öğretici", olmak üzere dört tema vardır. En çok metafor (29) "Fayda Durumu" temasindadır. Bu temadaki metaforların 18 tanesi olumsuz; 11 tanesi ise olumlu niteliktedir. Bu bağlamda öğrencilerin çoğunluğunun uzaktan eğitimle ilgili fayda bakımından olumsuz algılara sahip olduğu söylenebilir. 14 metafor bulunan "Öğretici"; 13 metafor bulunan "Okul" ve 9 metafor bulunan "İhtiyaç" temasındaki metaforların tamamı olumludur. Bu kategorideki bazı metaforik ifadeler şöyledir:

"Uzaktan eğitim yedek okul gibidir, çünkü okulumu çok aratmıyor." (ÖĞRN44, K, O, Okul)

“Uzaktan eğitim çöl gibidir, çünkü verim alamıyorum." (ÖĞRN115, K, Ü, Fayda Durumu)

“Uzaktan eğitim iftar açmak gibidir, çünkü eğitim açlığımızı gideriyor." (ÖĞRN105, E, L, İhtiyaç)

Erişim kategorisi altında "Kolaylık", "Teknik Sorun" ve "Yakınlık" olmak üzere üç tema bulunmaktadır. "Kolaylık" teması sekizi tekrarsız toplam 15 olmak üzere en çok metaforun bulunduğu temadır. Bu metaforlardan sadece bir tanesi olumsuzdur. "Yakınlık" teması altında bulunan üç metafor da olumludur. Bu bağlamda uzaktan eğitime erişim konusunda çoğunluğun olumlu algıya sahip olduğu söylenebilir. "Teknik Sorun" temasinda yer alan dört metaforun da olumsuz nitelikte olması uzaktan eğitime erişimde zaman zaman sorunlar yaşandığının bir göstergesi olabilir. Bu kategorideki bazı metaforik ifadeler şöyledir:

“Uzaktan eğitim telefon gibidir, çünkü her şeye bir tıkla erişebiliyorum."(ÖĞRN3, E, O, Kolaylık)

"Uzaktan eğitim sık sık arızalanan araba gibidir, sürekli bağlantıda kopukluk oluyor." (ÖĞRN27, K, Ü, Teknik Sorun)

"Uzaktan eğitim akraba gibidir, çünkü yanımızdadır." (ÖĞRN105, K, O, Yakınlık)

Esneklik kategorisinde "Kişiye Özel" ile "Zaman ve Mekân Bağımsızlığı" temaları bulunmaktadır. Her iki temadaki tüm metaforlar olumlu niteliktedir. Dolayısıyla uzaktan eğitimin zaman ve mekân bağımsızlığı sağlayarak esnek bir öğrenme ortamı sağlandığı söylenebilir. Bu kategorideki bazı metaforik ifadeler şöyledir: 
“Uzaktan eğitim online alışveriş gibidir, çünkü hiçbir zahmete girmeden oturduğumuz yerden istediğimiz şeyi elde edebiliriz." (ÖĞRN17, K, Ü, Zaman ve Mekân Bağımsızlığı)

"Müzik gibidir, istediğin tarzı dinlersin."(ÖĞRN93, K, O, Kişiye Özel)"

Etkileşim kategorisinde "İletişim ve Sosyalleşme" ile "Tek yönlülük" olmak üzere iki tema vardır. "İletişim ve Sosyalleşme" temasında dört olumlu, üç olumsuz toplam yedi metafor bulunmaktadır. "Tek yönlülük" temasındaki metaforların tamamı olumsuz niteliktedir. Bu kategorideki bazı metaforik ifadeler şöyledir:

“Uzaktan eğitim iplik gibidir, bizi birbirimize bağlar."(ÖĞRN93, K, Ü, İletişim ve Sosyalleşme)

"Sinema gibidir, sadece izleyebilirsin." (ÖĞRN17, K, O, Tek Yönlülük)

\section{Öğretmenlerin uzaktan eğitim algılarına ilişkin bulgular}

Öğretmenlerin uzaktan eğitime ilişkin metaforlarının ortaya çıkarılması ve uygun bir şekilde analiz edilebilmesi için öğretmenlerin uzaktan eğitim deneyimlerinin, kullanım sıklıklarının ve kullandıkları uzaktan eğitim platformlarının bilinmesi gerekmektedir. Tablo $6^{\prime}$ da bu hususlara ilişkin bilgiler bulunmaktadır.

Tablo 6. Öğretmenlerin uzaktan eğitim kullanım durumları

\begin{tabular}{llll}
\hline Uzaktan Eğitim & Tür & $\mathbf{f}$ & $\mathbf{\%}$ \\
\hline Uzaktan Eğitim & Evet & 122 & 90,4 \\
Deneyimi & Hayır & 13 & 9,6 \\
\hline \multirow{3}{*}{ Uzaktan Eğitim } & Haftalık 1-5 ders arasında & 86 & 63,7 \\
Kullanım Sıklığı & Haftalık 6-10 ders arasında & 24 & 17,8 \\
& Haftalık 11-15 ders arasında & 9 & 6,7 \\
& Haftalık 15 saat üzeri & 3 & 2,2 \\
& Hiç & 13 & 9,6 \\
\hline \multirow{3}{*}{ Tür } & Eba Canlı Ders & 86 & - \\
& Mesajlaşma uygulamalarındaki sinıf grupları & 87 & - \\
\hline
\end{tabular}

Tablo 6 incelendiğinde öğretmenlerin sadece \%9,6'sının aktif olarak uzaktan eğitim deneyimi olmadığı anlaşılmaktadır. Uzaktan eğitim kullanımında ise en çok haftalık 1-5 ders arası, ardından 6-10 ders arası sıklı̆̆ının belirtildiği görülmektedir. Uzaktan eğitim platformlarının kullanım oranları birbirlerine çok yakın olmakla birlikte en çok 
mesajlaşma uygulamalarındaki sınıf grupları ardından EBA canlı ders tercih edilmektedir. Kullanılan platformlar sorusunda birden fazla tür işaretlenebildiği için yüzdelik oranlar hesaplanmamıştır. Bu bağlamda öğretmenlerin ideal düzeyde uzaktan eğitim deneyimine sahip oldukları ve bu sistemi kullandıkları söylenebilir.

Öğretmenlerce oluşturulan metaforların kategorileri ile kategorilerdeki olumlu ve olumsuz metafor sayıları Tablo 7'de sunulmuştur.

Tablo 7. Öğretmen metaforlarının kategorileri ve nitelikleri

\begin{tabular}{lllllll}
\hline & Duyuşsal & Eğitim & Erişim & Esneklik & Etkileşim & Toplam \\
\cline { 2 - 7 } & $\mathbf{f}$ & $\mathbf{f}$ & $\mathbf{f}$ & $\mathbf{f}$ & $\mathbf{f}$ & $\mathbf{f}$ \\
\hline Olumlu Metafor & 14 & 44 & 10 & 10 & 10 & 88 \\
Olumsuz Metafor & 8 & 18 & 12 & 0 & 9 & 47 \\
\hline Toplam & 22 & 62 & 22 & 10 & 19 & 135 \\
\hline
\end{tabular}

Tablo 7 incelendiğinde öğretmenlerin uzaktan eğitimle ilgili oluşturdukları metaforların büyük bir çoğunluğunun $(\mathrm{f}=88)$ olumlu nitelikte olduğu görülürken, olumsuz nitelikte metafor belirten öğretmen sayısı ise $47^{\prime}$ dir. Bu verilerden hareketle öğretmenlerin uzaktan eğitim ile olumlu düşüncelere sahip olduğu söylenebilir.

Oluşturulan metaforlar kategori boyutlarına göre incelendiğinde, metaforların yarısına yakını (f=62) "Eğitim" kategorisindedir. "Duyuşsal" ve "Erişim" kategorilerinin eşit sayıda metaforla ikinci sırada yer alırken "Etkileşim" ve "Esneklik" kategorileri son sıradadır. "Eğitim" ve "Duyuşsal" kategorilerinde metaforlar çoğunlukla olumludur. "Esneklik" kategorisinde ise dikkat çekici bir şekilde oluşturulan metaforların tamamı olumludur. Her ne kadar oranlar birbirine yakın olsa da uzaktan eğitimle ilgili çoğunlukla olumsuz metaforların olduğu iki alan ise "Erişim" ve "Etkileşim" kategorileridir. Öğretmenlerin uzaktan eğitim metaforlarına ilişkin oluşan kategori ve temalar Tablo 8'de sunulmuştur.

Tablo 8. Öğretmenlerin uzaktan eğitim metaforlarına ilişkin kategori ve temalar

\begin{tabular}{|c|c|c|c|}
\hline Kategori & Tema & Benzetilen nesne & Metafor \\
\hline \multirow{3}{*}{ Duyuşsal } & Beklenmedik & Davetsiz misafir (2) & $\begin{array}{l}\text { Uzaktan eğitim davetsiz misafire benzer, çünkü } \\
\text { ne zaman kapıyı çalacağı bilinmez. }\end{array}$ \\
\hline & Eksiklik & Oyun, Pastayı ambalajla yemek & $\begin{array}{l}\text { Uzaktan eğitim oyun gibidir, çünkü öğrenciler } \\
\text { ciddiyetsiz. }\end{array}$ \\
\hline & Duygu & $\begin{array}{l}\text { Hasret gidermek, Randevu, Yuva, Ayna, } \\
\text { Parmaklıklar veya cam ardından çocuğunu } \\
\text { sevmek, Yol, Uzaktaki dağ }\end{array}$ & $\begin{array}{l}\text { Uzaktan eğitim yol gibidir, çünkü seni } \\
\text { özlediklerine götürür. }\end{array}$ \\
\hline
\end{tabular}




\begin{tabular}{|c|c|c|c|}
\hline & Memnuniyet & $\begin{array}{l}\text { Savaş uçağı, Can, Tablo, } 0-0 \text { biten maç, } \\
\text { Şekersiz içenler için şekerli çay, Hafta sonu } \\
\text { çalan alarm, Çikolata }\end{array}$ & $\begin{array}{l}\text { Uzaktan eğitim } 0-0 \text { biten maç gibidir, çünkü ne } \\
\text { seyircileri ne oyuncuları kimseyi mutlu etmez. }\end{array}$ \\
\hline & Motivasyon & $\begin{array}{l}\text { Oyun, Patlak top, Moral-motivasyon, Hedef } \\
\text { tahtasi }\end{array}$ & $\begin{array}{l}\text { Uzaktan eğitim patlak top gibidir, çünkü zevk } \\
\text { vermez. }\end{array}$ \\
\hline \multirow{9}{*}{ Eğitim } & Anlaşılmaz & İşkence, Dacia marka araç & $\begin{array}{l}\text { Uzaktan eğitim işkence gibidir, çünkü çocukların } \\
\text { anlaması zor. }\end{array}$ \\
\hline & Destek Ekipmanı & $\begin{array}{l}\text { Cankurtaran, Kötü gün dostu, Can simidi, } \\
\text { Ilk yardım ekibi, Kurtarıcı (2), Yara bandı, } \\
\text { Yedek lastik (2), Yama, Hiç yoktan iyi bir } \\
\text { şey, Denize düşenin yılana sarılması, } \\
\text { Mecburiyet }\end{array}$ & $\begin{array}{l}\text { Uzaktan eğitim yedek lastik gibidir, çünkü ana } \\
\text { mekanizma çalışmadığında devreye girer. }\end{array}$ \\
\hline & Sahte-Sanal & Plastik meyve, Emzik, Simülasyon, Film & $\begin{array}{l}\text { Uzaktan eğitim bir simülasyon gibidir, çünkü } \\
\text { gerçeği her zaman okuldadır. }\end{array}$ \\
\hline & Okul & $\begin{array}{l}\text { Gençlik, Dijital eğitim, Disipline etme yolu, } \\
\text { Okulda eğitim, Okulun ev hali, Sınıf } \\
\text { yoklaması }\end{array}$ & $\begin{array}{l}\text { Uzaktan eğitim okulun ev hali gibidir, çünkü tek } \\
\text { fark evde ders işlemektir. }\end{array}$ \\
\hline & Fayda & $\begin{array}{l}\text { Akıllı tahta, İlaç, Kamp ateşi, Ay, Gazı } \\
\text { kaçmış kola, Oksijen, Sürdürülebilir }\end{array}$ & $\begin{array}{l}\text { Uzaktan eğitim ay gibidir, çünkü karanlıkta } \\
\text { etrafımızı aydınlatır. }\end{array}$ \\
\hline & İhtiyaç & $\begin{array}{l}\text { Kişisel ihtiyaç, Telefon, Seçenek, Yoğurt } \\
\text { yapmak }\end{array}$ & $\begin{array}{l}\text { Uzaktan eğitim telefon gibidir, çünkü sürekli } \\
\text { ihtiyacımı vardır bu ortamda. }\end{array}$ \\
\hline & Öğretici & $\begin{array}{l}\text { Cemre, Rehber, Araba sürmek, Çağıı } \\
\text { anahtarı, Yol, Köprü, Film CD'si, Akraba, } \\
\text { Araba, } 4 \times 4 \text { bayrak koşusu }\end{array}$ & $\begin{array}{l}\text { Uzaktan eğitim cemre gibidir çünkü öğrenmeyi } \\
\text { müjdeler. }\end{array}$ \\
\hline & Verim & $\begin{array}{l}\text { Saklambaç, Kurtarıcı, Gübre, Kalitesiz } \\
\text { kumanda, Etkisiz eleman, Sanal arkadaşlık, } \\
\text { Tuzsuz yemek, Tatsız yemek, Suya yazılmış } \\
\text { yazı, Ahtapot, Verimli tarla, }\end{array}$ & $\begin{array}{l}\text { Uzaktan eğitim verimli bir tarla gibidir, çünkü } \\
\text { sınıf yönetimi derdim yok. }\end{array}$ \\
\hline & Yetersizlik & $\begin{array}{l}\text { Özet, Saman alevi, Tekeri patlak bisiklet, } \\
\text { Koltuk değneği, Fotoğraf karesi }\end{array}$ & $\begin{array}{l}\text { Uzaktan eğitim koltuk değneği gibidir, çünkü } \\
\text { koşmaya imkân vermez. }\end{array}$ \\
\hline \multirow{4}{*}{ Erişim } & Katılım & Kardelen, Gözlük, Bilgisayar, Zar & $\begin{array}{l}\text { Uzaktan eğitim bilgisayar gibidir, çünkü } \\
\text { açmadığımızda bilgi sahibi olamayız. }\end{array}$ \\
\hline & İmkân & $\begin{array}{l}\text { Alışveriş, Araba, Gerekli ama yetersiz, } \\
\text { Benzin, Otobüs bileti, } 5 \text { yıldızlı tatil, } \\
\text { Pringles, Ekmek, Telefon kontörü, Eşitsizlik } \\
\text { denklemi }\end{array}$ & $\begin{array}{l}\text { Uzaktan eğitim pringles gibidir, çünkü her çocuk } \\
\text { alamaz. }\end{array}$ \\
\hline & Kolaylık & $\begin{array}{l}\text { Sallama çay, Olanak, Perde, Klavye tuşu, } \\
\text { Sipariş }\end{array}$ & $\begin{array}{l}\text { Uzaktan eğitim sallama çay gibidir, çünkü kısa } \\
\text { sürede derse girersin. }\end{array}$ \\
\hline & Teknik sorun & Balık, Piyango, Elektrik kesintisi & $\begin{array}{l}\text { Uzaktan eğitim elektrik kesintisi gibidir, çünkü } \\
\text { aniden bağlantı kopar }\end{array}$ \\
\hline \multirow{2}{*}{ Esneklik } & Kişiye özel & Müzik, Çeşmeden akan su & $\begin{array}{l}\text { Uzaktan eğitim çeşmeden akan su gibidir, çünkü } \\
\text { ister testine doldurursun ister öylece bakarsn. }\end{array}$ \\
\hline & $\begin{array}{l}\text { Zaman ve mekân } \\
\text { Bağımsızlığı }\end{array}$ & $\begin{array}{l}\text { Homeofis, Uydu, Hava, Evde eğitim, } \\
\text { İnternet, İlaç, Örümcek ağı, Kuş }\end{array}$ & $\begin{array}{l}\text { Uzaktan eğitim uydu gibidir, çünkü saat yer } \\
\text { zaman fark etmeden ulaşabiliriz. }\end{array}$ \\
\hline \multirow{3}{*}{ Etkileşim } & $\begin{array}{l}\text { İletişim ve } \\
\text { Sosyalleşme }\end{array}$ & $\begin{array}{l}\text { Sohbet, Telefon, Yüz yüze eğitim, } \\
\text { Mesafeleri aşma, Etkileşimli tahta, Taş, } \\
\text { Güzel bir dokunuş, Pazaryeri, Ziyaret, } \\
\text { Seyircisiz maç, Rüya, Sanal öğretmen, }\end{array}$ & $\begin{array}{l}\text { Uzaktan eğitim park gibidir, çünkü arkadaşlarla } \\
\text { buluşma mekânıdır. }\end{array}$ \\
\hline & Engel & $\begin{array}{l}\text { Duvar, Sosyal mesafe, Gökyüzü, Gölge } \\
\text { oyunu }\end{array}$ & $\begin{array}{l}\text { Uzaktan eğitim sosyal mesafe gibidir, çünkü } \\
\text { arada görünmeyen duvarlar vardır. }\end{array}$ \\
\hline & Dönüt & Sınif, Robot öğretmen, Tuzsuz yemek & $\begin{array}{l}\text { Uzaktan eğitim robot öğretmen gibidir, çünkü } \\
\text { hep anlatır ama yeterli dönüt yoktur. }\end{array}$ \\
\hline
\end{tabular}

Tablo 8 incelendiğinde 5 kategori, 23 tema ve 125 tekrarsız metafor olduğu görülmektedir. Duyuşsal kategorisi "Beklenmedik", "Eksiklik", "Duygu", "Memnuniyet" ve "Motivasyon" olmak üzere beş tema içermektedir. "Memnuniyet" ve "Duygu" en çok metaforun (7) yer aldığ temalardır. Bu kategorideki bazı metaforik ifadeler aşağıda yer almaktadır. Metafor ifadelerinin yanında parantez içinde görüş sahibinin 
kodlanmış kimliği, cinsiyeti ("K" Kadın ve "E" Erkek) okul türü ("i' İlkokul, "O" Ortaokul," L" Lise) ve metaforun temasına yer verilmiştir.

"Uzaktan eğitim davetsiz gelen misafir gibidir, çünkü pijamalarla yakalandık" (ÖĞRT42, E, O, Beklenmedik)

"Uzaktan eğitim çok sevdiğiniz bir pastayı ambalajıyla yemek gibidir çünkü tadını tam alamazsın." (ÖĞRT123, K, O, Eksiklik)

"Uzaktan eğitim hasret gidermek gibidir, çünkü zorunlu görüş̧emediklerinle ulaşabilmektesin. (ÖĞRT28, E, O, Duygu)

"Uzaktan eğitim tablo gibidir, çünkü baktıkça bakasın gelir." (ÖĞRT121, K, L, Memnuniyet)

"Uzaktan eğitim hedef tahtası gibidir, çünkü hedefi olanlar motive olabilirler."(ÖĞRT39, E, O, Motivasyon)

Eğitim kategorisinde "Okul”, "Destek Ekipmanı", "Fayda Durumu”, "Sahte-Sanal", "İhtiyaç" ve "Öğretici" olmak üzere 6 tema bulunmaktadır. "Fayda Durumu" en çok metaforun (31) yer aldığ 1 temadır. Bu temadaki metaforların 17 tanesi olumlu; 14 tanesi ise olumsuz niteliktedir. Bu bağlamda öğretmenlerin çoğunluğu uzaktan eğitimle ilgili fayda bakımından olumlu algılara sahip olsa da arada net bir farklılık söz konusu değildir. "Destek Ekipmanı" temasında bulunan yedi metafordan sadece bir tanesinin olumsuz olması uzaktan eğitimin destekleyici bir unsur olarak kabul gördüğünün bir göstergesi olabilir. "Sahte-Sanal" temasında üç metafor olumsuz bir metafor ise olumludur. Bu bağlamda uzaktan eğitimin yüz yüze eğitime göre daha soyut kaldığı söylenebilir. 10 metafor bulunan "Öğretici", 6 metafor bulunan "Okul" ve 4 metafor bulunan "Ihtiyaç" temasındaki metaforların tamamı olumludur. Bu kategorideki bazı metaforik ifadeler şöyledir:

“Uzaktan eğitim yara bandı gibidir, çünkü ilaç değildir."(ÖĞRT84, E, O, Destek Ekipmanı)

"Plastik meyve gibidir, çünkü gerçeğinin yerini asla tutmaz." (ÖĞRT44, K, O, Sahte-Sanal)

"Okulda eğitim gibidir, çünkü iletişim araçları uzakları yakına taşımıştır." (ÖĞRT120, E, O, Okul)

“Gazı kaçmış kola gibidir, çünkü tat vermez." (ÖĞRT51, K, İ, Fayda Durumu)

Erişim kategorisi altında "Kolaylık", "Teknik Sorun", "Katılım" ve "İmkan" olmak üzere dört tema bulunmaktadır. "İmkan" teması sekiz 
tekrarsız toplam 10 olmak üzere en çok metaforun bulunduğu temadır. $\mathrm{Bu}$ metaforlardan sadece iki tanesi olumludur. Bu bağlamda uzaktan eğitimin donanımsal açıdan bir imkân meselesi olduğu söylenebilir. Öte yandan "Katılım" temasındaki metaforların üçü olumlu biri ise olumsuzdur. Son olarak "Kolaylık" temasındaki tüm metaforların olumlu olduğu görülmekteyken "Teknik Sorun" temasındaki metaforlar ise olumsuz niteliktedir. Dolayısıyla uzaktan eğitime erişimin kolay olmasına rağmen teknik sorunların var olduğu da bir gerçektir. Bu kategorideki bazı metaforik ifadeler şöyledir:

“Sipariş gibidir, çünkü ayağına gelir."(ÖĞRT115, K, O, Kolaylık)

"Uzaktan eğitim balık gibidir, çünkü internet gittikçe elimizden kayar." (ÖĞRT27, E, O, Teknik Sorun)

"Uzaktan eğitim 5 yıldızlı otelde tatil gibidir, çünkü imkân meselesidir." (ÖĞRT114, E, L, İmkân)

Esneklik kategorisinde "Zaman ve Mekân Bağımsızlığı" ile "Kişiye Özel" temaları bulunmaktadır. Her iki temada tüm metaforlar olumlu niteliktedir. Bu bağlamda uzaktan eğitimin bireylere zaman ve mekân bağımsızlığı sağlayarak esnek bir öğrenme ortamı sağladığı söylenebilir. Bu kategorideki temalara ait bazı görüşler şöyledir:

“Müzik dinlemek gibidir, çünkü öğretmenin de öğrencinin de keyfine kalmış bir uygulamadır."(ÖĞRT29, K, O, Kişiye Özel)

"Uzaktan eğitim internet gibidir, çünkü istediğim zaman erişebiliyorum." (ÖĞRT100, E, O, Zaman ve Mekân Bağımsızlığı)

Etkileşim kategorisinde "İletişim ve Sosyalleşme", “Dönüt" ve “Engel” olmak üzere üç tema bulunmaktadır. "İletişim ve Sosyalleşme" teması altında sekiz olumlu, dört olumsuz olmak üzere 12 metafor bulunmaktadır. "Dönüt" temasında ise iki olumsuz bir olumlu metafor bulunmaktadır. "Engel" temasındaki dört metafor tamamı olumsuz niteliktedir. Bu bağlamda öğretmenlerin uzaktan eğitimin engelleyici özellikleri olduğu konusunda hem fikir oldukları söylenebilir. Bu kategorideki bazı metaforik ifadeler şöyledir:

“Sanal bir öğretmendir, çünkü etkileşim ve temas yok."(ÖĞRT88, K, İ, İletişim ve Sosyalleşme)

"Duvar gibidir, çünkü kime ne anlatıyorsun kim ne anlıyor belli değil." (ÖĞRT17, E, O, Engel) 


\section{Öğrenci ve öğretmenlerin uzaktan eğitime yönelik algılarındaki benzer ve farklı noktalara ilişkin bulgular}

Öğrenci ve öğretmenlerin uzaktan eğitime ilişkin metaforlarının benzer ve farklı yönlerinin tespit edilmesinde öncelikle her bir kategorideki metafor sayıları ile olumlu ve olumsuz metafor sayıları incelenmiştir. $\mathrm{Bu}$ bağlamda oluşturulan Tablo 9 aşağıda yer almaktadır.

Tablo 9. Kategorilere ilişkin sayısal veriler

\begin{tabular}{lllllll}
\hline \multirow{2}{*}{ Kategori } & Öğrenci & \multicolumn{5}{c}{ Öğretmen } \\
\cline { 2 - 7 } & Olumlu & Olumsuz & Toplam & Olumlu & Olumsuz & Toplam \\
\hline Duyuşsal & 5 & 7 & 12 & 14 & 8 & 22 \\
Eğitim & 46 & 18 & 64 & 44 & 18 & 62 \\
Erişim & 17 & 6 & 23 & 10 & 12 & 22 \\
Esneklik & 16 & 0 & 16 & 10 & 0 & 10 \\
Etkileşim & 4 & 9 & 13 & 10 & 9 & 19 \\
Toplam & 88 & 40 & 128 & 88 & 47 & 135 \\
\hline
\end{tabular}

Tablo 9 incelendiğinde şu bulgular dikkat çekmektedir:

1. Her iki grupta toplam olumlu metafor sayısı $(\mathrm{f}=88)$ olumsuz metafor sayısindan fazladir.

2. "Eğitim" her iki grupta en çok metaforun oluşturulduğu kategoridir (Öğrenci $\mathrm{f}=64$; Öğretmen $\mathrm{f}=62$ ).

3. En az metafor ( $\mathrm{f}=12)$ öğrenci grubunda "Duyuşsal" kategorisinde; öğretmen grubunda "Esneklik" kategorisinde yer almaktadır ( $\mathrm{f}=10)$

4. Her iki grup arasında metafor sayısının en çok farklılaştığı kategori "Duyuşsal" kategorisidir (Öğrenci $\mathrm{f}=12$; Öğretmen $\mathrm{f}=22$ ).

5. İki grupta da "Esneklik" kategorisindeki tüm metaforlar olumludur.

6. Öğretmen grubunda tüm kategorilerde olumlu metaforların sayısı daha fazla iken öğrenci grubunda olumlu metafor sayısı olumsuz metafor sayısından az olan iki kategori (Duyuşsal-Etkileşim) vardır.

Her iki grubun oluşturduğu metaforların benzer ve farklı yönlerinin tespiti için ayrıca tema sayıları incelenmiştir. Ortak tema sayılarına ait bilgiler Tablo 10'da sunulmuştur.

Tablo incelendiğinde öğretmen metaforlarından ortaya çıkan 20; öğrenci metaforlarından ortaya çıkan 16 temanın büyük bir kısmının (11) ortak olduğu, tema benzerliğinin en çok olduğu kategorinin ise "Ĕ̆itim" 
olduğu görülmektedir. Dolayısıyla öğrenci ve öğretmenlerin uzaktan eğitim hakkında benzer metaforik algılara sahip olduğu söylenebilir.

Tablo 10. Temalara ilişkin sayısal veriler

\begin{tabular}{|c|c|c|c|}
\hline Kategori & Öğretmen Temaları & Öğrenci Temaları & Benzer tema sayısı \\
\hline \multirow{5}{*}{ Duyuşsal } & Motivasyon* & Motivasyon* & \multirow{5}{*}{2} \\
\hline & Eksiklik $^{*}$ & Eksiklik $^{*}$ & \\
\hline & Duygu & Bıkkınlık & \\
\hline & Memnuniyet & Şaşırtıcı & \\
\hline & Beklenmedik & Zorlayicl & \\
\hline \multirow{6}{*}{ Eğitim } & $\mathrm{Okul}^{*}$ & $\mathrm{Okul}^{*}$ & \multirow{6}{*}{4} \\
\hline & Fayda Durumu* & Fayda Durumu* & \\
\hline & İhtiyaç* & İhtiyaç & \\
\hline & Öğretici* & Öğretici* & \\
\hline & Destek Ekipmanı & - & \\
\hline & Sahte-Sanal & - & \\
\hline \multirow{4}{*}{ Erişim } & Kolaylik* & Kolaylik $^{*}$ & \multirow{4}{*}{2} \\
\hline & Teknik sorun* & Teknik sorun* & \\
\hline & Yakınlık & Katiltm & \\
\hline & İmkân & - & \\
\hline \multirow{2}{*}{ Esneklik } & Kişiye özel* & Kişiye özel* & \multirow{2}{*}{2} \\
\hline & Zaman ve mekan $b .^{*}$ & Zaman ve mekan $b$. & \\
\hline \multirow{3}{*}{ Etkileşim } & İletişim ve Sosyalleşme & İletişim ve Sosyalleşme & \multirow{3}{*}{1} \\
\hline & Engel & Tek yönlülük & \\
\hline & Dönüt & - & \\
\hline Toplam & 20 & 16 & 11 \\
\hline
\end{tabular}

Her iki grubun oluşturdukları metaforların benzer ve farklı yönlerinin ortaya konulması için uzaktan eğitimin benzetildiği nesnelerden kelime bulutu oluşturulmuştur. Öğrenci metaforlarından oluşan kelime bulutu Şekil 1'de yer almaktadır:

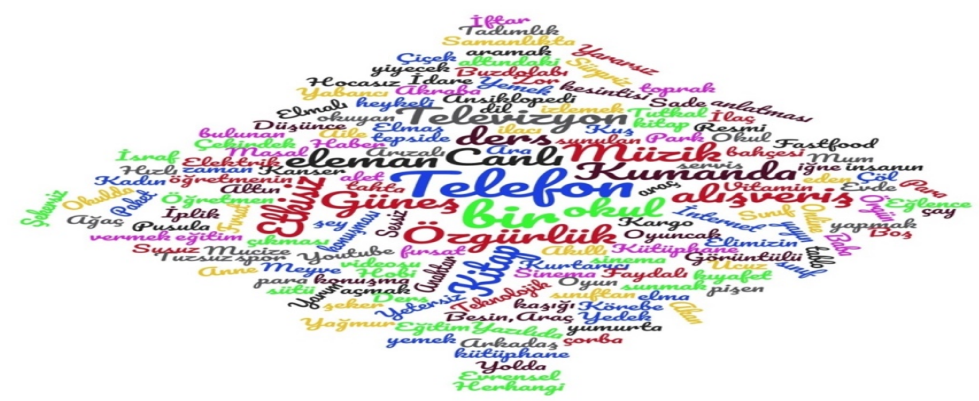

Şekil 1. Öğrencilerin uzaktan eğitimi benzettiği nesnelerden oluşan kelime bulutu 
Öğrenci kelime bulutu incelendiğinde en çok öne çıkan kelimenin "Telefon" olduğu görülmektedir. "Kumanda", "Canlı", "Müzik", “Televizyon", "Özgürlük", "Güneş" "Etkisiz" “Okul”, “Ders", "Alışveriş" ve "Kitap" gibi kelimelerin de öne çıktığı görülmektedir. Bu kelimeler içerisinde olumsuz nitelik taşıyan "Etkisiz" kelimesi göze çarpmaktadır. Bu bağlamda öğrencilerin önemli bir kısmının uzaktan eğitimi etkisiz bulduğu söylenebilir. Uzaktan eğitimin "Okul”, “Ders”, ve "Kitap" gibi kelimelerle ilişkilendirmesi öğrencilerin uzaktan eğitimi okula bir alternatif olarak gördüklerinin bir göstergesi olabilir. Kelime bulutundaki dikkat çekici bir diğer ifade ise "Özgürlük" kelimesidir. Bu ifade uzaktan eğitimin öğrencilere önemli derece esneklik sağladığının bir göstergesidir. "Güneş", "Müzik", "Kumanda", “Televizyon" ve "Alışveriş" gibi kelimelerle ilişkilendirilmesi uzaktan eğitimin öğrenciler tarafından bir ihtiyaç olarak görüldüğünün bir göstergesidir. Öğretmen metaforlarından oluşan kelime bulutu Şekil 2'de yer almaktadır:

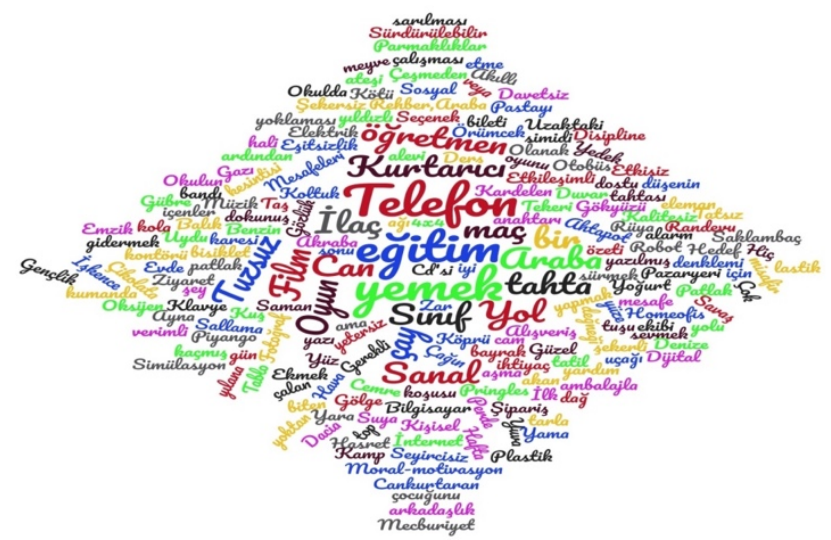

Şekil 2. Öğretmenlerin uzaktan ĕ̆itimi benzettiği nesnelerden oluşan kelime bulutu

Öğretmen kelime bulutu incelendiğinde en çok öne çıan kelimenin "Telefon" olduğu görülmektedir. Bunun yanı sıra "Eğitim", "Yemek", "Kurtarıc1", “Öğretmen", "Sınıf", "Araba", "Maç" "Yol”, “Tuzsuz", "Film" “Oyun", "Tahta”, "Can", "Illaç", "Çay" ve "Sanal” kelimelerinin öne çıktığı görülmektedir. "Öğretmen", "Sınıf", "Eğitim" “Tahta" ve 
"Yol" gibi kelimelerle uzaktan eğitimin ilişkilendirmesi öğretmenlerin uzaktan eğitimi okula bir alternatif ve yöntem olarak gördüklerinin bir göstergesi olabilir ki bu bulguya farklı kelimelerle ifade edilmiş olsa da öğrenci kelime bulutunda ulaşılmıştır. "Araba", "İlaç", "Çay", Yemek" ve "Kurtarıcı" gibi kelimeler uzaktan eğitimin öğretmenler tarafından bir ihtiyaç olarak görüldüğü şeklinde yorumlanabilir. Benzer şeklide bu bulguya öğrenci kelime bulutunda da rastlanmıştır. "Maç", "Film" ve "Oyun" kelimeleri ise uzaktan eğitimin öğretmenlere göre güdüleyici özellikler taşıdığının bir göstergesi olarak yorumlanabilir. Kelime bulutunda uzaktan eğitim ile ilgili olumsuz nitelik taşıyabilecek ifadeler ise "Sanal" ve "Tuzsuz" kelimeleridir.

Her iki grubun kelime bulutları incelendiğinde genel itibariyle benzetilen nesnelerin çoğunluğu olumlu niteliktedir. Uzaktan eğitimin en çok benzetildiği nesne telefon olarak göze çarpmaktadır. Bu bağlamda telefonun günümüz koşullarında bilgiye ulaşmada kullanılan en hızlı ve pratik araç olmasından dolayı sağlamış olduğu kolaylık, esneklik ve zaman ve mekân gözetmeksizin işlevselliği telefonun uzaktan eğitimle ilişkilendirilmesinin sebebi olabilir.

\section{Tartışma ve Sonuç}

Bu çalışmada öğrenci ve öğretmenlerin uzaktan eğitime yönelik algıları metaforlar aracılığıyla incelenmiştir. Çalışma sonucunda hem öğrencilerin hem de öğretmenlerin uzaktan eğitime yönelik olumlu ve benzer algilara sahip olduğu sonucuna ulaşılmıştır.

"Eğitim" hem öğrenciler hem de öğretmenler tarafından en çok metafor üretilen kategoridir. Üretilen metaforlara çoğunlukla olumlu anlamlar yüklenmesi "uzaktan eğitimin" bir öğretim uygulaması olarak öğrenci ve öğretmenlerce kabul gördüğü, yüz yüze eğitimden farklı görmedikleri sonucunu ortaya çıarmaktadır. Bu kategori altında çoğunlukla okul, öğretici, ihtiyaç gibi temaların oluşması bu sonucu destekler niteliktedir. Erten (2020) "gerçek sınıf-okul ortamı ile aynı olma" kategorisinin öğrenciler tarafından en çok metafor oluşturulan kategorilerinden biri olduğunu belirtmektedir. Benzer şekilde Fidan (2017)'ın çalışmasında eğitim, en çok metafor üretilen kategoridir. Uzaktan eğitimin katılımcılar tarafından normal eğitime benzer 
görülmesi, salgın sonrası eğitim sistemin bir parçası olması düşünülen uzaktan eğitimin kabul ve entegrasyonunu kolaylaştıracağ düşünülmektedir.

"Erişim" öğrenciler ve öğretmenlerce en çok metafor oluşturulan ikinci kategoridir. $\mathrm{Bu}$ kategoride öğrencilerce oluşturulan metaforların çoğunluğu olumlu iken öğretmenlerce oluşturulan metaforların çoğunluğu olumsuzdur. Çalışmaya katılan öğrencilerin büyük çoğunluğunun uzaktan eğitim deneyimi olması ve uzaktan eğitime erişim imkânına sahip olmaları öğrencilerin olumu metaforlar üretmesinin sebebi olarak düşünülmektedir. Öğretmenler ise daha geniş bir bakış açısıyla düşünerek uzaktan eğitime çeşitli imkânsızlıklar sebebiyle katılamayan öğrencilerin olduğu hususuna metaforlar aracilığıyla dikkat çekmektedirler. Karaca ve Kelam (2020) öğretmenlerin, öğrenci menfaatlerini ve onların eğitim hakkını gözettiği ayrıca bunun bir meslek etiği olduğunu düşündüklerini vurgulanmaktadır. Bu bağlamda öğretmenlerin uzaktan eğitime erişim hususuna eleştirel yaklaştıkları sonucu çıkarılabilir.

Erişim kategorindeki temalar incelendiğinde öğrenciler daha çok kolaylık ve yakınlık temalı metaforlar üretirken öğretmen metaforları ise imkân ve katılım temalarında yoğunlaşmıştır. Tuncay ve Özçınar (2009)'ın çalışmasında katılımcıların \%66'sının uzaktan eğitimi metaforik olarak "zengin öğrencilerin eğitimi" şeklinde tanımlamaları bu araştırmanın sonuçlarını desteklemektedir. Eken, Tosun ve Eken (2020) uzaktan eğitim uygulamalarındaki en önemli sorunun, yeterli imkânları olmayan veya düşük sosyoekonomik düzeye sahip öğrencilerle diğer öğrenciler arasında eğitime erişim konusunda büyük farklar oluşması olduğunu belirtmektedir. Benzer şekilde Bozkurt (2020)'un çalışmasında eşitsizlik teması ile ortaya çıkan "erişim" sorunu Taşkıran (2017) tarafından "farklı sosyo-ekonomik altyapıya sahip birey veya grupların iletişim teknolojisine erişim imkânı ve bu teknolojilerin kullanım amaçları" şeklinde ifade edilen dijital bölünme kavramıyla açıklanmıştır. Bu bağlamda her öğrenciye uzaktan eğitime erişim imkânı sağlanması, dijital bölünme kaynaklı eşitsizliklerin giderilmesi ve uzaktan eğitimin maddiyatla ilişkili olduğu algısının ortadan kaldırılması uzaktan eğitimin sosyolojik olarak kabulünü kolaylaştırıcı bir etmen olacaktır. 
Erişim kategorisinde her iki grubun da teknik sorun kısmında olumsuz metaforlar oluşturması uzaktan eğitim sürecinde teknik sorunlar yaşandığını ortaya koymaktadır. Salgınla birlikte ülkenin tamamında sadece eğitim faaliyetlerinin değil birçok kamusal faaliyetin internet tabanlı yürütülmesi, internet altyapısının bu duruma hazırlıklı olmaması, uzaktan eğitim sistemlerinin acil bir şekilde devreye konulması (EBA canlı ders vb.) dolayısıyla teknik sorunların ortaya çıkması olağan bir sonuç olarak görülmektedir.

"Esneklik" kategorisi öğrencilerin en çok metafor oluşturduğu üçüncü kategori iken öğretmenlerin en az metafor oluşturduğu gruptur. Bu bağlamda öğrencilerin uzaktan eğitimin sağlamış olduğu esnekliği önemli gördüğü, öğretmenlerin ise esnekliğe daha az önem verdiği sonucu çıkarılabilir. Bu kategori altındaki metaforların tamamının olumlu nitelikte olması esnekliğin uzaktan eğitimin sağlamış olduğu en büyük avantaj olduğunu ortaya koymaktadır. Çivril vd. (2018) öğrencilerin çoğunun, uzaktan eğitimin esneklik sağladığını belirten metaforlar kullandıklarını çalışmalarında tespit etmiştir. Umurhan (2014) uzaktan eğitimin sağlamış olduğu esneklik, zaman ve mekân bağımsızlığının öğretim elemanlarını uzaktan eğitime teşvik eden unsurlar arasında yer aldığını vurgulamaktadır.

Salgın dönemindeki uzaktan eğitim algılarının tespit edilmesini amaçlayan bir metafor analizi çalışmasında Bozkurt (2020) zaman ve mekândan bağımsız öğrenme anlayışıyla hayat boyu öğrenme becerilerinin kazanılması bakımından öğrencilerin uzaktan eğitimin sağlamış olduğu esnekliği keşfetmelerinin, uzaktan eğitimin geleceği açısından önemli olduğunu ifade etmektedir. Güçlü (2020) hayat boyu öğrenmenin teknoloji, okul, örgün öğretim, sanat-kültür, aile ve endüstri üzerinde önemli etkileri olduğunu ifade etmektedir. Teknolojinin eğitim ve öğretim hizmetleriyle bütünleşmesi ve dijitalleşmenin artarak devam etmesi, gelecekte şu anda ki durumdan daha çok zaman ve mekândan bağımsız bir şekilde bireysel öğrenme gereksinimi ortaya çıkarmakta ve bireylerin hayat boyu öğrenme becerilerine katkı sağlamaktadır. Dolayısıyla uzaktan eğitimin, oluşan bu beklenti ve ihtiyacı karşılayabilecek güçlü bir alternatif olduğu söylenebilir.

"Etkileşim" kategorisinde öğrenci grubunda çoğunlukla olumsuz metaforlar bulunmaktadır. Öğretmen grubunda ise olumlu ve olumsuz 
metafor sayıları neredeyse birbirine eşittir. Çivril vd. (2018) ve Bozkurt (2020)'un çalışmalarında olumsuz metaforlar arasında en çok öne çıkan grubun etkileşim kategorisi olduğu görülmektedir. Avcı ve Akdeniz (2021)'in çalışmasında yeteri düzeyde öğretmen-öğrenci iletişimin kurulamaması uzaktan eğitimin sıklıkla belirtilen problemlerdendir. Bu bağlamda uzaktan eğitimde karşılıklı etkileşimin sınırlı olduğu sonucu ortaya çıkmaktadır.

Etkileşim kategorisindeki olumsuz temaların öğrenci grubunda tek yönlülük, öğretmen grubunda ise engel başlıkları altında toplandığ 1 görülmektedir. Yılmaz ve Güven (2015)'in çalışmasında sınıf öğretmeni adayı öğretmenler tarafından oluşturulan metaforların önemli bir kısmının etkileşimsiz kategorisinde olduğu görülmektedir. Bu bağlamda eş zamanlı veya eş zamansız fark etmeksizin uzaktan eğitimde etkileşim sinırlılığı olduğu sonucu ortaya çıkmaktadır. İbicioğlu ve Antalyalı (2005) etkileşimsiz bir uzaktan eğitimin dersin kavranmasında sorun oluşturmasa da eğitimin derinliği açısından sınıf ortamındaki başarıyı sağlayamadığını ifade etmektedir. Özetle uzaktan eğitim sürecinde iletişim ve etkileşim düzeyi ne kadar yüksek olursa, uzaktan eğitimden elde edilen başarı ve memnuniyetin o ölçüde artacağı söylenebilir.

"Duyuşsal" kategorisi öğrenciler ve öğretmenler arasında en çok farklılığın bulunduğu gruptur. Bu kategori öğrencilerin en az metafor ürettiği kategori iken, öğretmenlerin erişim kategorisiyle birlikte en çok metafor ürettiği ikinci kategoridir. Metafor özellikleri incelendiğinde öğrenci grubunda daha çok olumsuz metaforlar bulunurken öğretmen grubunda olumlu metaforlar daha fazladır. Bu bağlamda öğrencilerin uzaktan eğitimin motivasyon, beklenti, duygu gibi duyuşsal öğeler içeren yönüne daha az önem verirken öğretmenlerin uzaktan eğitimin duyuşsal yönüne daha çok değer atfettikleri anlaşılmaktadır.

Öğrencilerin uzaktan eğitime duyuşsal yönden olumsuz anlamlar yüklemeleri, uzaktan eğitimden yararlanma düzeyini olumsuz etkileyebilmektedir. Fidan (2017) uzaktan eğitimde dikkat edilmesi gereken önemli noktalardan birinin hem öğrenenlerin hem de eğiticilerin duyuşsal nitelikli özellikleri olduğunu, duyuşsal kaynaklı sorunların altında iletişim ve etkileşim eksikliğinin olduğunu vurgulamaktadır. Bu bağlamda uzaktan eğitimde öğrenen ve öğrenci arasındaki etkileşim düzeyi ile duyuşsal algılar arasında doğru orantılı bir ilişki olduğu 
söylenebilir. Nitekim duyuşsal kategorisinin katılımcı öğretmenlerce en çok metafor oluşturulan kategori olması hem de çoğunlukla olumlu metaforlar üretilmesi oldukça anlamlı görünmektedir. Öğretmenlerin uzaktan eğitimden kaynaklanan fiziksel uzaklığın duygusal bir uzaklığa dönüşmemesi hususunda bilinçli oldukları söylenebilir.

Öğrenci ve öğretmenlerin salgın döneminde gerçekleştirilen uzaktan eğitime yönelik algılarının incelendiği bu çalışmada katılımcıların büyük oranda uzaktan eğitimle ilgili olumlu algılara sahip olduğu sonucuna ulaşılmıştır. Katılımcılar tarafından oluşturulan metaforlarda, uzaktan eğitimin erişim, esneklik, eğitim, etkileşim ve duyuşsal boyutlarına vurgu yapıldığı görülmektedir. Dolayısıyla uzaktan eğitim sistemlerinin tasarlanması, eğitim sistemine entegrasyonu ve uygulanması sürecinde bu boyutların göz önünde bulundurulması önerilmektedir. 


\title{
EXTENDED ABSTRACT
}

\section{Distance Education Perceptions of Students and Teachers during Covid-19 Epidemic: A Metaphor Analysis \\ *}

\author{
Murat Çokyaman - Menderes Ünal \\ Ahi Evran University
}

Due to the Covid-19 epidemic, which started in China in 2019 and spread all over the world, the concept of distance education has begun to be pronounced frequently. Due to this global epidemic, schools have been closed in many countries and in some countries, lessons have been tried to be compensated through distance education. Turkey is one of the countries where distance education is used the most. Distance education or interaction, which started with student-teacher groups in messaging applications, continued with mutual conversation programs based on the teleconference system.

In the distance education activities in the first period of the Covid-19 epidemic, each student and teacher benefited from different distance education tools according to their own opportunities and personal situation. Therefore, everyone has a different perception of distance education in their minds. For example, some teachers or students may be participating in distance education activities voluntarily, while others may be participating due to various obligations, or some may find this situation useful, while others may consider it useless. In this context, it is important to reveal the perception of distance education in the minds of individuals. With this study, it was aimed to reveal the perceptions of students and teachers about distance education through metaphors. The concept of distance education in this study, in particular, refers to the educational activities carried out through distance education programs, programs based on the teleconference system and student-teacher groups in messaging applications in order to compensate for the educational activities that could not be done face-to-face in the first period of the Covid-19 epidemic. In line with the purpose of the research, answers to the following questions were sought: 
1. What are the metaphorical perceptions of students about distance education?

2. What are the metaphorical perceptions of teachers about distance education?

3. What are the similar and different points in the metaphorical perceptions of students and teachers towards distance education?

This study is a qualitative research designed with a phenomenological pattern. Phenomenology studies aim to gain a deeper understanding of the nature or meaning of our daily experiences (Patton, 2002). The universe of the study consists of students and teachers in a city located in the Central Anatolia Region in Turkey. Convenience sampling method was used in the study due to the current epidemic period. Convenience sampling is a method that is based on accessibility and convenience and enables rapid collection of research data (Berg, 2001). Participants were asked to create a metaphor about distance education. As a result of the collected data, 314 participants filled the form. The data obtained were examined and the data that did not show the metaphor feature were excluded from the study and the total number of participants was determined as 263, 135 teachers and 128 students.

In order to reveal the perceptions of the participants about "distance education", a data collection tool was prepared via Google forms. Opinions were received from 3 educational science experts for the prepared form. The first part of the data collection tool is for the determination of demographic characteristics. In this section, demographic characteristics vary depending on whether the participation status is a student or a teacher. In the second part, it is aimed to determine the distance education experiences of the participants. In the last part, in order to determine the metaphors of distance education, the participants were asked to complete the following sentence :"Distance Education is like ........ because ..............". Data were collected by sharing the web link of the prepared data collection tool with the participants. The metaphors obtained from the study were analyzed by content analysis.

When the metaphors created by the participants were analyzed, five categories emerged as "Affective", "Education", "Access", "Flexibility", and "Interaction". The study of Çivril et al. (2018) was benefited in the creation of categories and themes. Of the metaphors produced by the students, 88 
are positive and 40 are negative. Half of the metaphors ( $\mathrm{f}=64)$ produced by the students are in the "Education" category. Similarly, 88 of the metaphors produced by teachers are positive and 47 are negative. Almost half of the metaphors $(\mathrm{f}=62)$ produced by teachers are in the "Education" category. In addition, when the word cloud of the metaphors created by the participants was examined, the metaphor of "Telephone" came to the fore in both groups. In this context, it can be said that the metaphorical perceptions of students and teachers about distance education are similar to each other. When the metaphors created are examined in terms of categories, positive metaphors are in the majority in both groups in the "Education" and "Flexibility" categories, even all metaphors in the flexibility category are positive. While students' metaphors are more positive in the "Access" category, teachers' metaphors are more positive in the "Interaction" and "Affective" categories.

In this study, which searched the perceptions of students and teachers about distance education during the epidemic, it was concluded that the participants had positive and similar perceptions about distance education to a large extent. It was seen that the metaphors created by the participants emphasized the access, flexibility, education, interaction and affective dimensions of distance education. Therefore, it is recommended to consider these dimensions in the design, integration and implementation of distance education systems.

\section{Kaynakça / References}

Akyürek, M. (2020). Uzaktan eğitim: Bir alanyazın taraması. Medeniyet Eğitim Araştırmaları Dergisi, 4(1), 1-9.

Alkan, C. (1987). Ĕ̆itim teknolojisi. Ankara: Yargıcıŏglu Matbaası.

Arat, T. ve Bakan, Ö. (2014). Uzaktan eğitim ve uygulamaları. Selçuk Üniversitesi Sosyal Bilimler Meslek Yüksekokulu Dergisi, 14(1-2), 363-374.

Avcı, F. ve Akdeniz, E. (2021). Koronavirüs (Covid-19) salgını ve uzaktan eğitim sürecinde karşllaşllan sorunlar konusunda öğretmenlerin değerlendirmeleri. Uluslararası Sosyal Bilimler ve Eğitim Dergisi, 3(4), 117-154.

Aydoğdu, E. (2008). Illköğretim okullarındaki öğrenci ve öğretmenlerin sahip oldukları okul algilarn ile ideal okul algilarinin metaforlar (mecazlar) yoluyla 
analizi. (Yayımlanmamış yüksek lisans tezi). Osmangazi Üniversitesi, Eskişehir.

Aykaç, N. ve Çelik, Ö. (2014). Öğretmenlerin ve öğretmen adaylarının eğitim programına ilişkin metaforik algılarının karşılaştırılması. Ĕ̆itim ve Bilim, 39, 328-340.

Berg, B. L. (2001). Qualitative research, message for the social sciences. Boston: Allin and Bacon.

Bozkurt, A. (2020). Koronavirüs (Covid-19) pandemisi sırasında ilköğretim öğrencilerinin uzaktan eğitime yönelik imge ve algıları: Bir metafor analizi. Uşak Üniversitesi Eğitim Araştırmaları Dergisi, 6(2), 1-23. doi: 10.29065/usakead.777652.

Çivril, H., Aruğaslan, E. ve Özkara, B. (2018). Uzaktan eğitim öğrencilerinin uzaktan eğitime yönelik algıları: Bir metafor analizi. Eğitim Teknolojisi Kuram ve Uygulama, 8(1), 39-59. doi: 10.17943/etku.310168.

Demir, E. (2014). Uzaktan eğitime genel bir bakış. Dumlupınar Üniversitesi Sosyal Bilimler Dergisi, 39, 203-212.

Eken, Ö., Tosun, N. ve Eken, D. (2020). Covid-19 salgını ile acil ve zorunlu uzaktan eğitime geçiş: genel bir değerlendirme. Milli Ĕ̆itim Dergisi, 49(1), 113-128. doi: 10.37669/milliegitim.780722

Elcil, Ş. ve Şahiner, D. (2014). Uzaktan eğitimde iletişimsel engeller. Sosyal ve Beşeri Bilimler Dergisi, 6(1), 21-33.

Erten, P. (2020). Bilgisayar ve öğretim teknolojileri öğretmen adaylarının sanal sınıflara yönelik metaforik algıları. Bolu Abant İzet Baysal Üniversitesi Eğitim Fakültesi Dergisi, 20(1), 133-148.

Fidan, M. (2017). Metaphors of blended learning' students regarding the concept of distance education. International Online Journal of Educational Sciences, 9(1), 276-291.

Gökbulut, B. (2021). Uzaktan eğitim öğrencilerinin bakış açısıyla uzaktan eğitim ve mobil öğrenme. Eğitim Teknolojisi Kuram ve Uygulama, 11(1), 160-177. doi:10.17943/etku.797164.

Güçlü, M. (2016). Türkiye'de uzaktan eğitim uygulamaları: Tarihsel gelişim açısından bir değerlendirme. International Congresses on Education, 1(1), 689-695.

Güçlü, M. (2020). Yaşam boyu öğrenmenin önemi ve temel özellikleri. M. Güçlü (Der.), Yetişkin eğitimi ve hayat boyu öğrenme, içinde (s.124-132). Ankara: Pegem Akademi. 
İbicioğlu, H. ve Antalyalı, U. Ö. L. (2005). Uzaktan eğitimin başarısında imkân alg1 motivasyon ve etkileşim faktörlerinin etkileri: Karşılaştırmalı bir uygulama. Çukurova Üniversitesi Sosyal Bilimler Enstitüsü Dergisi, 14(2), 325-338.

İrani, T., R. Telg., C. Scherler ve M. Harrington. (2003). Personality type and its relationship to distance education students' course perceptions and performance. Quarterly Review of Distance Education, 4(4), 445-453.

Karaca, Ş. ve Kelam, D. (2020). COVID-19 gölgesinde uzaktan eğitim hizmet kalitesinin incelenmesi. Sivas Interdisipliner Turizm Araştırmaları Dergisi, 5, 7-18.

Karataş, S. (2008). Temel kavramlar ve kuramsal temeller. H. İ. Yalın (Der.), Internet temelli eğitim, içinde (s.8-29). Ankara: Nobel Yayınları.

Kılınç, M. (2015). İnönü Üniversitesi uzaktan eğitim merkezi ilahiyat lisans tamamlama programı örneği. (Yayımlanmamış doktora tezi). İnönü Üniversitesi, Malatya.

Kırali, F. N. ve Alcı, B. (2016). Üniversite öğrencilerinin uzaktan eğitim algısına ilişkin görüşleri. İstanbul Aydın Üniversitesi Dergisi, 8(30), 5583.

Moore, M. (2002). Information and communication technologies in distance education. UNESCO Institute for Information Technologies in Education.

Moore, M. G. ve Kearsley, G. (1995). Distance education: A system view. Belmont: Wadsworth.

Patton, M. Q. (2002). Qualitative research and evaluation methods. Hershey: PA: Sage.

Sackmann, S. (1989). The role of metaphors in organization transformation. Human Relations, 42(6), 463-485. doi: 10.1177/001872678904200601

Schutz, P. A. and Pekrun, R. (2007). Introduction to emotion in education. P. A. Schutz and R. Pekrun, (Eds.) içinde. Emotion in education (p. 3-10). San Diego, CA: Academic Press.

Taşkıran, A. (2017). Açık ve uzaktan öğrenmede dijital bölünme. Açıköğretim Uygulamaları ve Araştırmaları Dergisi, 3(4), 108-124.

Tuncay, N. ve Özçınar, Z. (2009). Distance education students' metaphors. Procedia Social and Behavioral Sciences, 1(1), 2883-2888.

Umurhan, H. (2014). Öğretim elemanların uzaktan eğitime teşvik eden unsurlar: Gazi üniversitesi örneği. (Yayımlanmamış yüksek lisans tezi). Gazi Üniversitesi, Ankara.

Uşun, S. (2006). Uzaktan eğitim. Ankara: Nobel Yayın Dağıtım. 
Yıldırım, A. ve Şimşek, H. (2016). Sosyal bilimlerde nitel araştırma yöntemleri. Ankara: Şeçkin Yayınları.

Yılmaz, G. ve Güven, B. (2015). Öğretmen adaylarının uzaktan eğitime yönelik algilarının metaforlar yoluyla belirlenmesi. Turkish Journal of Computer and Mathematics Education, 6(2), 299-322. doi: 10.16949/turcomat.75936.

\section{Kaynakça Bilgisi / Citation Information}

Çokyaman, M. ve Ünal, M. (2021). Öğrenci ve öğretmenlerin Covid-19 salgını dönemindeki uzaktan eğitim algısı: Bir metafor analizi. OPUS-Uluslararası Toplum Araştırmaları Dergisi, 18(Yönetim ve Organizasyon Özel Sayıs1), 1684-1715. DOI: 10.26466/opus.913396. 